Jahangirnagar University J. Biol. Sci. 6(1): 1-12, 2017 (June)

\title{
Comparative activity pattern and feeding behaviour of Capped Langur (Trachypithecus pileatus) and Rhesus Macaque (Macaca mulatta) in Madhupur National Park of Bangladesh
}

\author{
Monirujjaman* and M. Monirul H. Khan \\ Department of Zoology, Jahangirnagar University, Savar, Dhaka 1342, Bangladesh
}

\begin{abstract}
Comparative activity pattern and feeding behaviour of Capped Langur (Trachypithecus pileatus) and Rhesus Macaque (Macaca mulatta) were studied in Madhupur National Park of Bangladesh from September 2015 to September 2016. Scan sampling method with 5 minutes interval was followed in the field. The Capped Langur spent $42 \%$ of the day time in feeding, $45 \%$ in resting, $6 \%$ in moving, $4 \%$ in playing, $2 \%$ in grooming and $1 \%$ in breeding, whereas the Rhesus Macaque spent $24 \%$ of the day time in feeding, $26 \%$ in resting, $30 \%$ in moving, $15 \%$ in playing, $4 \%$ in grooming and $1 \%$ in breeding. The Capped Langur spent comparatively more $(7.25 \%)$ time in feeding than the Rhesus Macaque. Seasonal variation in feeding of the Capped Langur is more obvious than that in the Rhesus Macaque. Both species started their feeding activities early in the morning and stopped at late afternoon. Diet of the Capped Langur comprises of plant food (94\%), animal food (3\%), water (1\%) and food offered by men (2\%), and diet of the Rhesus Macaque comprises of plant food (79\%), animal food (4\%), soil $(1 \%)$, water $(2 \%)$ and food offered by men $(14 \%)$. Both are mainly vegetarian but fed on varieties of food. It was found that the Capped Langur is primarily folivorous (48\%) and the Rhesus Macaque is primarily frugivorous (55\%). The Capped Langur fed on a total of 51 species of plant under 28 families and Rhesus Macaque fed on 38 species of plant under 18 families. The Capped Langur consumed more natural food (98\%) than that of Rhesus Macaque (86\%); the rest were food offered by men. The day ranges of Capped Langur and Rhesus Macaque were 400 metres and 550 metres, respectively. No notable conflict between Capped Langur and Rhesus Macaque was observed while feeding.
\end{abstract}

Key words: Activity, feeding, Capped Langur, Rhesus Macaque, National Park, Bangladesh.

\section{INTRODUCTION}

Because of its geographical location at the eastern end of the Indian Subcontinent, Bangladesh is a transitional zone of the flora and fauna between South and Southeast Asia. A total of 182 species of non-human primates under 14 families are found in the whole world, of which 25 species are found in South Asia (Roonwal \& Mohnot, 1977). Among them, in Bangladesh ten species of primates have been recorded (Feeroz et al., 1995). Among them, macaques and langurs have been subject to a great scientific interest for many years in the field of laboratory ecology, behaviour, and adaptation to a wide range of habitats (Hosen, 2011).

\footnotetext{
*Corresponding author. E-mail: monirujjamankhan912@ gmail.com
} 
In the wild, a primate's food consumption is related to seasonality, habitat quality, food abundance, distribution (Jaman, 2008) and nutritional properties of food items. Activity budgets are related to important physiological and environmental factors such as energy balance, body size and food availability (Clutton-Brock, 1974). Diet and habitat structure are known to affect time spent in activities because of trade-offs between obtaining food and the costs in energy of doing so. Temperature influences a plant's rate of growth and its nutritional content (Jaman, 2008). This has both direct and indirect effects on the seasonality of the activity budget of species dependant upon plants for food (Dunbar, 1992). Activity budgets in wild Japanese Macaques (Macaca fuscata) can be affected by seasonal changes in temperature and this can vary with age and sex. It is expected therefore that age-sex class activity patterns should be different. The objectives of this study were to know the different aspects of activity pattern and feeding of Capped Langur and Rhesus Macaque in a comparative perspective, with reference to the feeding frequency and types of food items eaten, utilization of canopy, etc.

Study Area: Madhupur National Park is located in Tangail and Mymensingh districts, 125 kilometers north of Dhaka. The park is located in the northeast of Tangail Forest Division along the boundary with Mymensingh district. It is located from $24^{\circ} 36^{\prime}$ to $24^{\circ} 42^{\prime}$ North latitudes and $90^{\circ} 00^{\prime}$ to $90^{\circ} 06^{\prime}$ East longitudes. Madhupur National Park is located in three Upazilas (sub-districts): Madhupur Upazila in Tangail District and Muktagacha and Fulbaria Upazillas in Mymensingh District. Major parts of the park are under the administrative jurisdiction of Tangail Forest Division and a small portion is under the jurisdiction of Mymensingh Forest Division. The tract is known as Madhupur Garh, comprises an area of 8436.13 hectors (Khan, 2014). Madhupur National Park has four ranges, ten beats, and one nursery center. It is part of the tropical moist broadleaf ecoregion of Bangladesh and eastern India. It was declared a National Park on 24 February 1982 under the Bangladesh Wildlife Act of 1974 (Khan, 2014), although calls for national park status began as early as 1962 .

\section{MATERIALS ANDMETHODS}

The scan sampling method at 5 minute intervals were used based on Altman (1974), Chivers (1984), Ahsan (1994), Gupta (1996), Feeroz et al. (1995), and Kabir (1991). An interval of 5 minutes ensures that each scan is usually discrete from the previous one, an essential requirement to satisfy conditions for statistical analysis. Data were collected on one group, each group of Capped Langur and Rhesus Macaque for two to four consecutive days in every month from September 2015 to September 2016. Activities of all visible individuals of the group were recorded in each scan. Each behaviour of one individual during each scan was recorded as one observation. Feeding is defined as the intake of solid food or water into the mouth, followed by ingesting food or masticating and search for food items on the ground or in vegetation where food is typically found. Resting is defined as when an animal remains stationary and inactive or no other behavior occurs. Moving is defined as terrestrial or arboreal locomotion, from one place to another, by the process of running, climbing, and walking except when searching for food and playing. Playing is defined as jumping, hanging on, mounting on the back of mother or 
another individual or grasping others in a non-threatening context. They show wrestle play, chase play, and solitary play. Grooming is defined as the animal pick through or /and brushes aside the fur of another using one or both hands. Breeding is defined as try to ejaculation or any initiatives of copulation. The canopy was divided into 3 levels, on the basis of their ranges in this deciduous forest -- top canopy: approximately $30-40 \mathrm{~m}$ in height, middle canopy: approximately $20-30 \mathrm{~m}$ in height, and lower canopy: approximately ground to $20 \mathrm{~m}$ in height.

The total study period was 48 days ( 24 days for Capped Langur and 24 days for Rhesus Macaque) from September 2015 to September 2016. A total of 498 hours (250 hours for Capped Langur and 248 hours for Rhesus Macaque), 5,976 scans (3,000 scans for Capped Langur and 2,976 scans for Rhesus Macaque), and 21,780 observations (8,560 observations for Capped Langur and 13,220 observations for Rhesus Macaque) were made for field data collection.

The studied group of Capped Langur consists of 8 individuals. One adult male (12.5\%) leads the group between the two adult females (25\%). There are also one sub-adult male $(12.5 \%)$ and one sub-adult female (12.5\%). One juvenile (12.5\%) and two infants (25\%) are very nice to see. The studied group of Rhesus Macaque, on the other hand, was recorded as multi-male and multi-female social system. The size and composition of social groups vary geographically because of habitat structure and food availability. There were 13 individuals in the present study group. Two adult males (15.39\%) lead the group between the three adult females $(23.07 \%)$. There are also two sub-adult males $(15.39 \%)$ and two sub-adult females (15.39\%). One juvenile (7.69\%) and three infants (23.07\%) are very nice to see.

\section{RESULTS AND DISCUSSION}

Based on the present observation it was concluded that the activity of the Capped Langur throughout the day was $42 \%$ of their daytime in feeding, $45 \%$ time in resting, $6 \%$ time in moving, $4 \%$ time in playing, $2 \%$ time in grooming and $1 \%$ time in breeding. Seasonal variation in the feeding of Capped Langur was significant $\left(\chi^{2}=120.107, \mathrm{df}=60, \mathrm{p}<5 \%\right)$. Movement of the Capped Langur was recorded under three subcategories e.g. walking, jumping, and climbing. Resting was the highest activity of Capped Langur of this study site. Resting was recorded under two subcategories e.g. sleeping and sitting. The Rhesus Macaque, on the other hand, activity throughout the day was $24 \%$ of their daytime in feeding, 26\% time in resting, 30\% time in moving, $15 \%$ time in playing, $4 \%$ time in grooming and $1 \%$ time in breeding. Seasonal variation in the feeding of Rhesus Macaque was significant $\left(\chi^{2}=105.74, \mathrm{df}=60, \mathrm{p}<5 \%\right)$. Moving of Rhesus Macaque was recorded under three subcategories, i.e. walking, jumping and climbing. Moving was the highest activity of Rhesus Macaque of this study site. Resting was recorded under two subcategories, i.e. sleeping and sitting.

The comparative study (Figure 1) shows that Capped Langur spent time in resting $>$ feeding $>$ moving $>$ playing $>$ grooming $>$ breeding, and Rhesus Macaque spent time in moving $>$ resting $>$ feeding $>$ playing $>$ grooming $>$ breeding. The Capped Langur spent most 
of the time in resting and the Rhesus Macaque spent most of the time in moving, so no notable conflict between Capped Langur and Rhesus Macaque was observed while feeding.

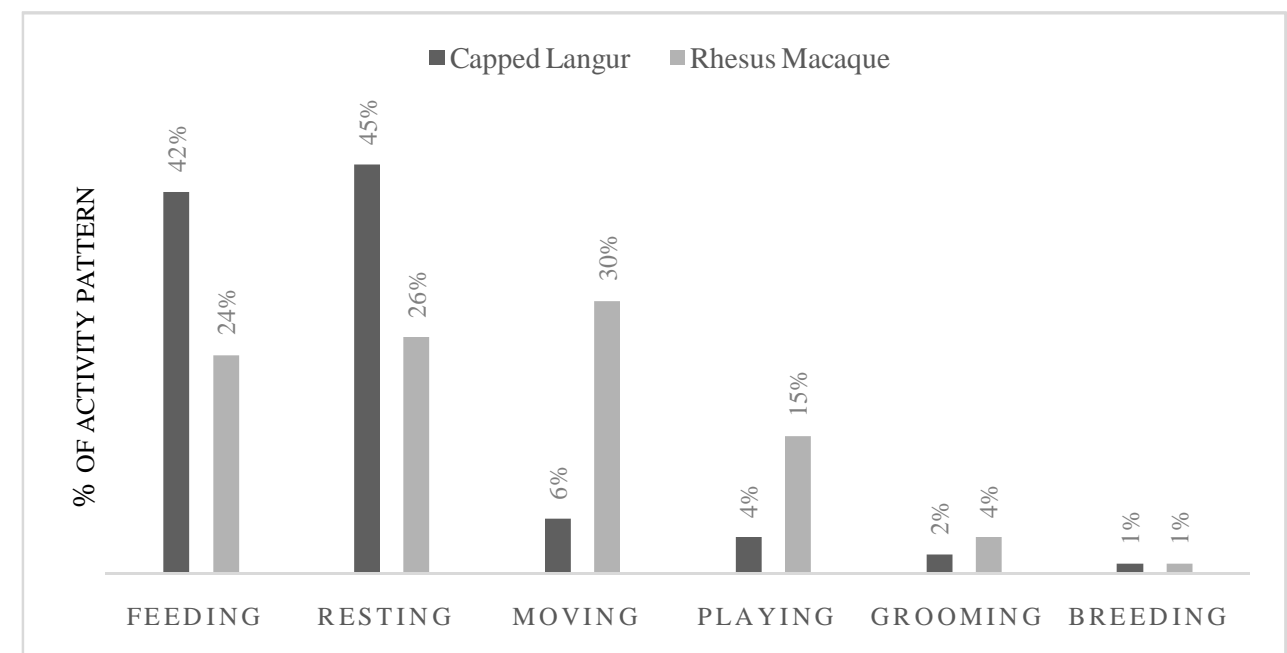

Fig. 1. Overall comparative activity pattern of Capped Langur and Rhesus Macaque during the study period

The monthly activity budget for feeding was calculated from the monthly data of the group. During the study period, the Capped Langur spent most of their time (105 hours) in feeding (42\%). The highest was in October 2015 (9.24 hours) and the lowest was in May 2016 (4.62 hours). The feeding behaviour varied significantly across the hours of the every month $\left(\chi^{2}=159.64, \mathrm{df}=12, \mathrm{p}<5 \%\right)$. The Rhesus Macaque, on the other hand, spent most of their time (59.52 hours) in feeding (24\%). The highest was in August 2016 (5.28 hours) and the lowest was in July 2016 (2.64 hours). The feeding behaviour varied significantly across the hours of the every month $\left(\chi^{2}=26.19, \mathrm{df}=12, \mathrm{p}<5 \%\right)$. The comparison of hourly feeding shows that the Capped Langur fed the highest in October 2015 and lowest in May 2016, and Rhesus Macaque fed the highest in August 2016 and lowest in July 2016 (Figure 2).

The major activity of the Capped Langur throughout the day was resting (45\%). Feeding (42\%) was the second major activity. There were two feeding peaks in the day; one in the morning between 6.30 am to $10.00 \mathrm{am}(13.8 \%)$ and the other was in the afternoon at 3.30 $\mathrm{pm}$ to $6.00 \mathrm{pm}(10.5 \%)$. The major activity of Rhesus Macaque throughout the day was moving (30\%). Feeding (24\%) was the third major activity and resting (26\%) was the second major activity. There were two feeding peaks in the day: one in the morning between 7.00 am to $9.00 \mathrm{am}(11.5 \%)$ and the other was in the afternoon at $4.00 \mathrm{pm}$ to $6.00 \mathrm{pm}(8.75 \%)$. The Capped Langur covered approximately 400 metres and Rhesus Macaque covered approximately 550 metres area as the day range, but it varied from place to place, season to season, the number of animals and other activities performed by the same animals (Alom, 2015). 


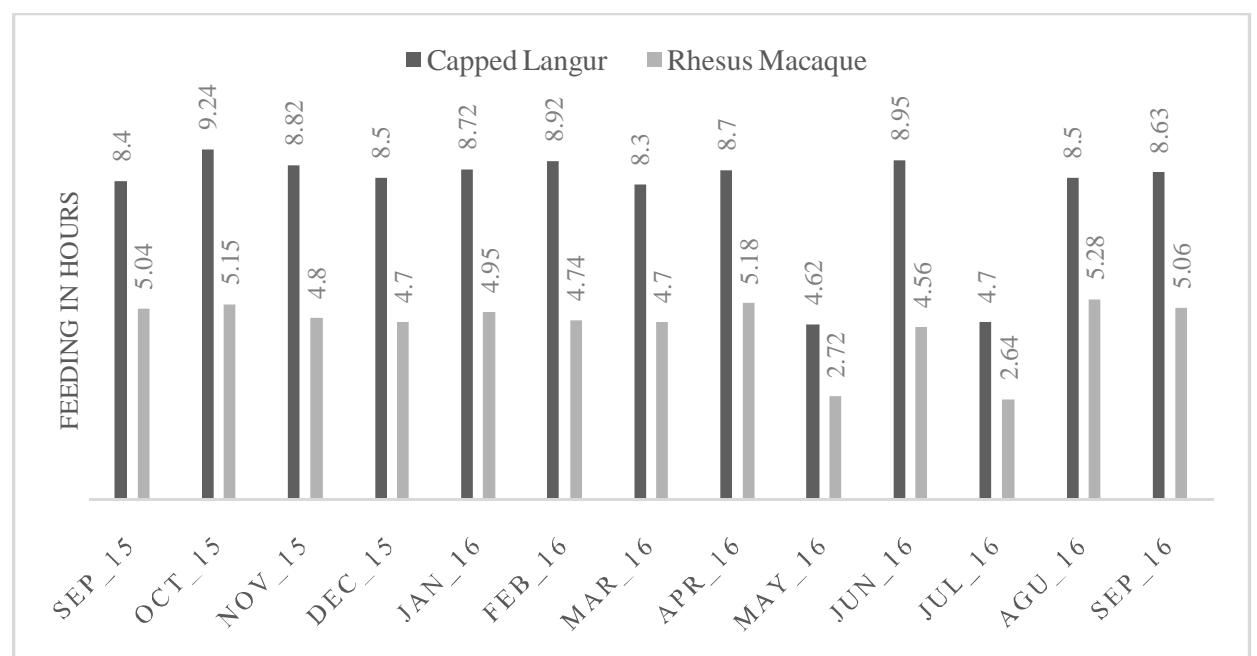

Fig. 2. Comparative monthly variation of feeding in hours in Capped Langur and Rhesus Macaque

The diet of Capped Langur comprises of plant food (94\%), animal food (3\%), water (1\%), and food offered by men (2\%) (Figure 3). Plant food is the main food source of Capped Langur at Madhupur National Park. The diet of Rhesus Macaque, on the other hand, comprises of plant food (79\%), animal food (4\%), soil (1\%), water (2\%), and food offered by men (14\%) (Figure 3). The Capped Langur depends more on plant food (94\%) than Rhesus Macaque (79\%), whereas the Rhesus Macaque depends more on food offered by men (14\%) than that of Capped Langur (2\%). For this reason, no notable conflict between Capped Langur and Rhesus Macaque was observed while feeding.

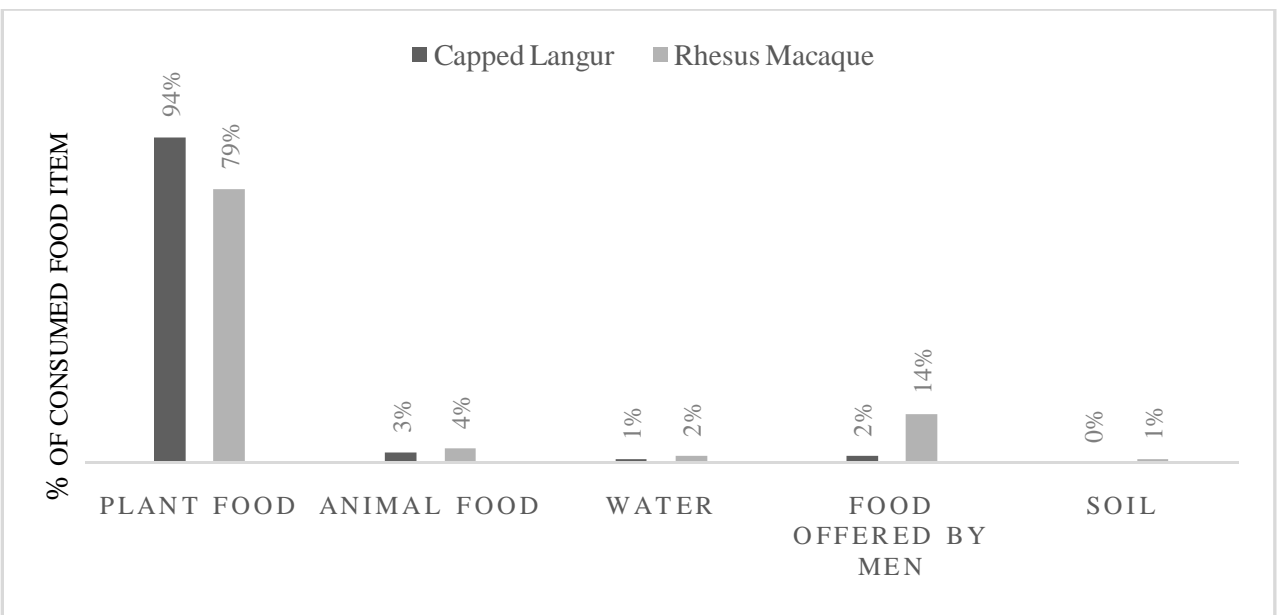

Fig. 3. Comparative food item of Capped Langur and Rhesus Macaque 
A total of 69 plant species comprised the diet of both Capped Langur and Rhesus Macaque (Table 1), plants were identified from the "Encyclopedia of Flora and Fauna of Bangladesh", published during 2007-2009 and some references publications (Alom, 2015 \& Sarker, 2008). The diet of Capped Langur comprises of fruits (28\%), leaves (48\%), shoots (3\%), barks (1\%), seeds (4\%), petioles (11\%), and flowers (5\%) (Figure 4). A total of 51 plant species under 28 families comprised the diet of Capped Langur. Leaves are the main food sources of Capped Langur at Madhupur National Park. They consumed both young and mature leaves. They were found to take several types of leaves e.g. Kadam (Neolemerckia cadamba), Akashmoni (Acacia auricoliformis), Sal (Shorea robusta), and Bot (Ficus bengalensis). The diet of Rhesus Macaque, on the other hand, comprised of fruits $(55 \%)$, leaves $(23 \%)$, flowers $(2 \%)$, shoots $(10 \%)$, petioles $(3 \%)$, seeds (4\%), and barks (2\%) (Figure 4). A total of 38 plant species under 18 families comprised the diet of Rhesus Macaque. Fruits are the main food sources of Rhesus Macaque at Madhupur National Park. They consumed both ripe and unripe fruits. They were found to take several types of fruits e.g. Anaras (Ananas comosus), Kamranga (Averrhoa carambola), Chapalish (Artocarpus chaplasha) and Cluster Fig (Ficus racemosa). Some invertebrates and vertebrates consumed by both Capped Langur and Rhesus Macaque.

Table 1. List of plant food consumed by Capped Langur and Rhesus Macaque

\begin{tabular}{|c|c|c|c|c|}
\hline \multirow[t]{2}{*}{ Scientific name } & \multirow[t]{2}{*}{ Common name } & \multirow[t]{2}{*}{ Family } & \multicolumn{2}{|c|}{ Part eaten } \\
\hline & & & C. L. & R. M. \\
\hline Acacia auricoliformis & Akashmoni & Leguminosae & - & Le \\
\hline Adnia cordifolia & Kaika, Holdu & Rubiaceae & Le & Le \\
\hline Albizia procera & Koroi & Leguminosae & - & Le, fr \\
\hline Alstonia scholaris & Chatian & Apocynaceae & $\mathrm{Fl}$, pe & - \\
\hline Ananas comosus & Anaros & Bromeliaceae & - & Fr \\
\hline Antidesma bunius & Shialbuka & Euphorbiaceae & - & $\mathrm{Fr}$ \\
\hline Aphanamixis polystachya & Pithraj Tree & Milliaceae & Le & - \\
\hline Artocarpus chaplasha & Chaplisha & Moraceae & $\mathrm{Fr}$ & $\mathrm{Fr}$ \\
\hline Artocarpus heterophylius & Kathal & Moraceae & - & $\mathrm{Fr}$ \\
\hline Artocarpus lakoocha & Dauwa & Moraceae & Fr & Fr \\
\hline Averrhoa carambola & Kamranga & Averrhoaceae & - & $\mathrm{Fr}$ \\
\hline Axonopus compressus & Ghash & Gramineae & - & $\mathrm{Sh}$ \\
\hline Bambosa sp. & Bash & Gramineae & - & Le, sh \\
\hline Barringtonia recemosus & Itchytree & Lecythidaceae & Le & - \\
\hline Bridelia sp. & Bridelia & Euphobiaceae & Le, fr & - \\
\hline Bursera serrata & Niyar & Burseraceae & Le, fr, se & - \\
\hline Callicaspa arborea & Bormala & Verbenaceae & - & $\mathrm{Fr}$ \\
\hline Capparis decidua & Kerda & Capparidaceae & Le & - \\
\hline Careyaar borea & Kumbi & Lecythidaceae & Le & - \\
\hline Cassia fistula & Bandar Lathi & Leguminosae & Le, fr & $\mathrm{Fr}$ \\
\hline Cynodon dactylon & Durba & Gramineae & - & $\mathrm{Sh}$ \\
\hline Dalbergia sissoo & Sissoo & Leguminosae & Le, fr & - \\
\hline Derris sp. & Derris & Leguminosae & $\mathrm{Le}$ & - \\
\hline Dillenia pentagyna & Ajuli & Dilleniaceae & Le, fl & - \\
\hline Dioscorea sp. & Gach Alu & Dioscoreaceae & - & $\mathrm{Fr}$ \\
\hline
\end{tabular}




\begin{tabular}{|c|c|c|c|c|}
\hline Eucaliptus globulus & Blue Gum & Myrtaceae & - & $\mathrm{Br}$ \\
\hline Ficus bengalensis & Banyan, Bot & Moraceae & Le, fr & - \\
\hline Ficus racemosa & Cluster Fig & Moraceae & Le, fr & $\mathrm{Fr}$ \\
\hline Ficus religiosa & Bodhi Tree & Moraceae & Le, br & Le, fr \\
\hline Gmelina arborea & Gamari & Verbenaceae & Le & $\mathrm{Fr}$ \\
\hline Hevedora siliensis & Shila & Euphorbidaceae & $\mathrm{Pe}$ & - \\
\hline Hibiscus rosasinensis & Joba & Malvaceae & Le, sh & - \\
\hline Hymenodictyon excelsum & Bhotum & Rubiaceae & - & Le \\
\hline Kydia calycina & Kidia & Malvaceae & Le, fr, pe & - \\
\hline Lagerstroemia parviflora & Bolsidai & Lythraceae & Le, fl & - \\
\hline Lagerstroemia speciosa & Jarul & Lythraceae & $\mathrm{Pe}$ & - \\
\hline Lannea coromandelica & Jigar & Anacardiaceae & Le, fr & Fr \\
\hline Lannea grandis & Kashmala & Anacardiaceae & Le, pe & - \\
\hline Litsea lauraceae & Bollygum & Lauraceae & Le & - \\
\hline Mallotus phillipensis & Sinduri & Euphorbiaceae & Le & Fr \\
\hline Mangifera indica & Aam (Mango) & Anacardiaceae & Fr & $\mathrm{Fr}$ \\
\hline Micromelum pubescens & Tanyin & Rutaceae & Le & - \\
\hline Mikania cordata & Bikas & Compositae & Le & Le \\
\hline Miliusa velutina & Gandi Gajari & Annonaceae & Le & - \\
\hline Moringa olefera & Sajna & Moringaceae & Le & - \\
\hline Mucuna prurita & Kapikachu & Leguminosae & $\mathrm{Se}$ & - \\
\hline Musa paradisiaca & Kola & Musaceae & - & $\mathrm{Fr}$ \\
\hline Neolemerckia cadamba & Kadam & Rubiaceae & $\mathrm{Fr}$ & - \\
\hline Oryza sativa & Dhan & Gramineae & - & Le, sh \\
\hline Phyllanthus emblica & Amlaki & Euphorbiaceae & Le, fr & $\mathrm{Fr}$ \\
\hline Psidium guajava & Peyara & Myrtaceae & - & $\mathrm{Fr}$ \\
\hline Randia sp. & Mankata & Randiaceae & Le, fr & $\mathrm{Fr}$ \\
\hline Samanea saman & Rain Tree Koroi & Leguminosae & Le & - \\
\hline Sapium baccatum & Bolos & Euphorbiaceae & - & $\mathrm{Fr}$ \\
\hline Shorea robusta & Sal & Dipterocarpaceae & Le, sh & Le, sh \\
\hline Smilax macrophylla & Catbriers & Liliaceae & Fr, sh & Fr, sh \\
\hline Spatholobus roxburghii & Kuntze & Leguminosae & $\mathrm{Fl}, \mathrm{se}, \mathrm{pe}$ & Fl, se, pe \\
\hline Spondias mangifera & Jongli Aam & Anacardiaceae & $\mathrm{Fr}$ & $\mathrm{Fr}$ \\
\hline Streblus asper & Sahora & Moraceae & Le & Le \\
\hline Syzygium cumini & Jam & Myrtaceae & Le, fr & Le, fr \\
\hline Syzygium fruticosum & Ban Jam & Myrtaceae & $\mathrm{Fr}$ & - \\
\hline Tectona grandis & Tiikki & Lamiaceae & $\mathrm{Pe}$ & - \\
\hline Terminalia arjuna & Arjun & Combretaceae & Le & - \\
\hline Terminalia belerica & Bahera & Combretaceae & Le, pe & - \\
\hline Terminalia chebula & Haritaki & Combretaceae & Le, fr, pe & Le, fr, pe \\
\hline Tephrosia candida & Tephrosia & Leguminosa & Le, fr & - \\
\hline Vitis vinifera & Angur & Vitaceae & $\mathrm{Fr}$ & - \\
\hline Zizypus rugosaus & Jangli Boroi & Rhamnaceae & Le & - \\
\hline Zyzyphus mauritiana & Boroi & Rhamnaceae & - & $\mathrm{Fr}$ \\
\hline
\end{tabular}

[Key: Le $=$ leave, $\mathrm{fr}=$ Fruit, $\mathrm{fl}=$ flower, $\mathrm{sh}=$ shoot, $\mathrm{pe}=$ peotile, $\mathrm{se}=$ seed, $\mathrm{br}=$ bark, and $-=$ not eaten $]$

The comparative study (Figure 4) shows that the Capped Langur fed on leaves $>$ fruits $>$ petioles $>$ flowers $>$ seeds $>$ shoots $>$ barks and Rhesus Macaque fed on fruits $>$ leaves $>$ shoots $>$ seeds $>$ petioles $>$ flowers $>$ barks. Since the Capped Langur fed on 
leaves most of the time and Rhesus Macaque fed on fruits most of the time, there was no notable conflict for food between the two primate species coexisting in the same forest.

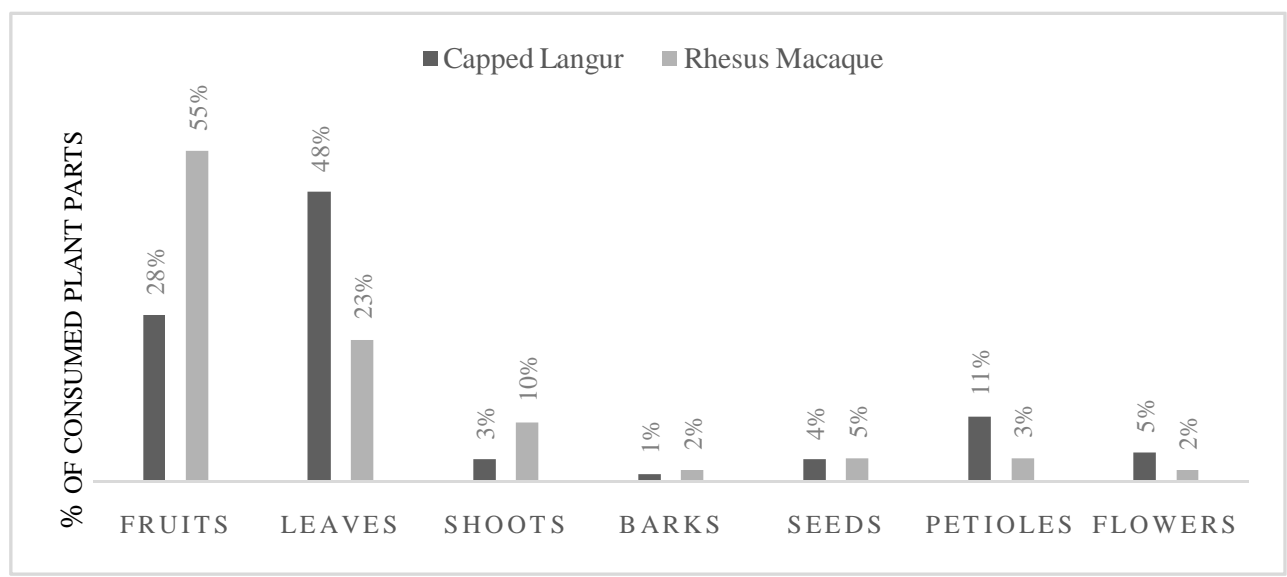

Fig. 4. Comparative percentages of plant parts consumed by Capped Langur and Rhesus Macaque during the study period

The Capped Langur spent 60\% time on top canopy, 35\% time on middle canopy and 5\% time on lower canopy. The Rhesus Macaque, on the other hand, spent 3\% time on top canopy, 64\% time on middle canopy and 33\% time on lower canopy (Figure 5). Because of the differences in canopy preference, no noticeable conflict was observed between the two species.

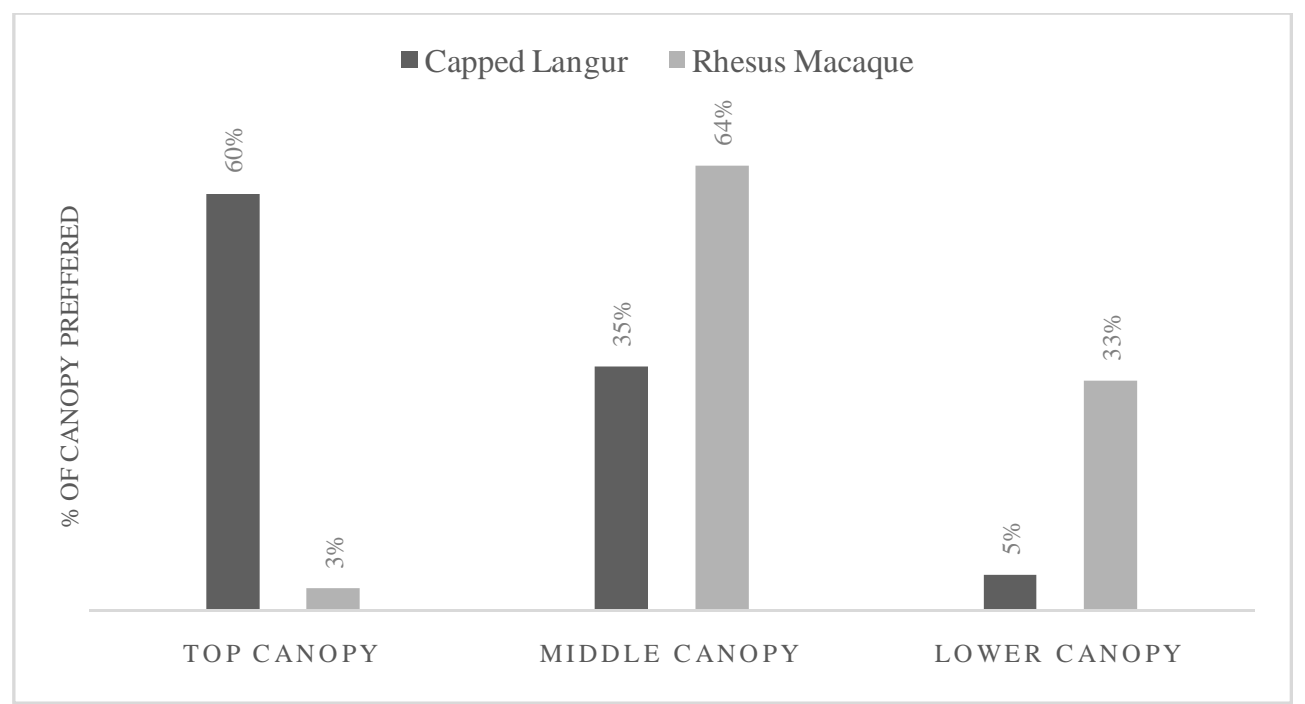

Fig. 5. Comparative percentages of canopy preferred by Capped Langur and Rhesus Macaque during the study period 
In Madhupur National Park the free ranging Capped Langur groups get their food from the forest or from the nearby villages. The Capped Langur obtained $98 \%$ food from the natural sources. The rest $2 \%$ were the food offered by humans, e.g. Banana, biscuit, bread, rice. The Rhesus Macaque, on the other hand, get their food from the forest or from the nearby villages, but it obtained lesser proportion (86\%) of food from the natural sources. The rest $14 \%$ were the food offered by humans, e.g. apple, banana, biscuit, bread, chips, guava, nut, papaya, plum, pulse, rice.

The Capped Langur lived mainly on the upper canopy and rarely come in contact with local people or visitors. As a result, it receives a small amount of food offered by people. The Rhesus Macaque, on the other hand, lives mainly on the lower canopy and often come in close contact with people. It even snatches food from visitors and raids the kitchen of the local households to get food.

Sometimes Capped Langurs and Rhesus Macaques were seen feeding on insects. The Capped Langurs fed on caterpillars of butterflies and dragonflies. The Rhesus Macaque, on the other hand, fed on spiders, spider eggs, moths, caterpillars, dragonflies, grasshoppers, and termites. The Capped Langur was found to spend $1 \%$ of its active feeding time in drinking, Rhesus Macaque was found to spend $2 \%$ of their active feeding time in drinking. The Capped Langur drinks water from the ponds, rainwater, tree holes and coconut, and the Rhesus Macaque drink water from ponds, rainwater, tree holes, ditches, tube-wells, market taps, waterhole and other reservoirs.

Among the group members of the Capped Langurs, adult female (30\%) spent relatively more time in feeding than the adult male (26\%). The sub-adult male spent $19 \%$ time in feeding while the sub-adult female spent $15 \%$. Juvenile spent (8\%) time in feeding. Infant spent the minimum amount (2\%) of feeding (lactation and another feeding). Among the group members of the Rhesus Macaque, adult female (29\%) spent relatively more time in feeding than the adult male (25\%). The sub-adult male spent $18 \%$ time in feeding and the sub-adult female spent $16 \%$. The juvenile spent $9 \%$ time in feeding. Infant spent the minimum amount (3\%) of time in feeding in the form of lactation and others.

All primate species are highly selective in their choice of food, often consistently selecting specific parts of a particular species (Glutton-Brock, 1977). The most important factors affecting food choice are likely to be proteins, digestible carbohydrates, sodium, tannin, fiber, and toxins (Freeland, 1974; Oates, 1977).

Mandal (2014) observed that the Capped Langur spent 35.67\% time in feeding, 36.38\% in resting, $10.5 \%$ in moving and $17.45 \%$ in other activities of their total time at Madhupur National Park. This study found out that the Capped Langur spent $42 \%$ of daytime in feeding. This variation in feeding may be due to the fact that the two works were done in the significant gap of time, allowing the ecological changes in both study sites.

The Capped Langur is largely vegetarian (Jaman et al., 2010). Its diet includes leaves, fruits, flowers, seeds etc. Kabir (1991) reported that Capped Langurs spent 39\% time in 
feeding, $47 \%$ time in resting, $9 \%$ time in moving, $3 \%$ time in playing and $2 \%$ time in the grooming of their day time at Madhupur National Park, but this study found that Capped Langur spent $42 \%$ of daytime in feeding. Kabir (1991) found that Capped Langurs eat plant parts of 30 identified species, the main items of their diet are leaves (61\%), fruits (27\%), flowers (6\%) and buds (3\%), but in this study it was found that the Capped Langur eats plant parts of 51 identified plant species. These differences were probably due to the differences in food availability at Madhupur National Park. Kabir (1991) observed that Capped Langurs spent $34 \%$ time in feeding, $46 \%$ time in resting, $12 \%$ time in moving, $5 \%$ time in playing and 3\% time in grooming of their day time at West Bhanugach Reserved Forest, but this study shows that Capped Langur spent $42 \%$ of daytime in feeding. This may be due to more food found in Madhupur National Park than West Bhanugach Reserved Forest.

Although the Rhesus Macaque is known to be vegetarian, the observation during this study indicates this species consumed varieties of the item as food. Sarker (2008) reported that the Rhesus Macaque spent 16\% time in the feeding at Barmi, Gazipur, Bangladesh. He reported that the Rhesus Macaque feeds mainly on natural food (71.9\%), but also on leftover of human food and food offered by humans $(28.1 \%)$. In this study, it was found that the Rhesus Macaque consumed monthly $86 \%$ food from natural resources and $14 \%$ food offered by men.

Hosen (2011) reported that the Rhesus Macaque spent 20\% time in feeding, 23.83\% time in resting, $26 \%$ time in moving, $11.5 \%$ time in foraging, $5 \%$ time in playing, $8 \%$ time in grooming, $2 \%$ time in aggression, $2 \%$ time in lactation, and $1 \%$ time in breeding of their total time at Madhupur National Park. He also reported that the Rhesus Macaque consumed of leaves $(62.66 \%)$, fruits $(8.49 \%)$, shoots $(4.35 \%)$, seeds $(1.45 \%)$, insects $(0.65 \%)$ and food offered by men $(22.4 \%)$. They fed on $(77.6 \%)$ natural foods and (22.4\%) food offered by men.

Badal (2011) reported that the Rhesus Macaque spent 27.36\% time in feeding, $19.26 \%$ time in resting, $37.12 \%$ time in moving, and $16.26 \%$ in social activities of their total time at Shariatpur, Bangladesh. Among their diet fruits constitute the highest amount (38\%), vegetables $(26 \%)$, grains $(27 \%)$, and animal foods $(9 \%)$. In this study, the Rhesus

Macaque was found to spend similar proportion of time (24\%) in feeding, but consumes less proportion (4\%) of animal food.

\section{REFERENCES}

Ahmed, Z.U., Begum, Z.N.T., Hassan, M.A., Khondker, M., Rahman, M.M., Kabir, S.M.H., Ahmad, M., Ahmed, A.T.A., Rahman, A.K.A. and Hoque, E.U. 2007-2009. Encyclopedia of Flora and Fauna of Bangladesh. Vols 1-28. Asiatic Society of Bangladesh. Dhaka.

Ahsan, M.F. 1994. Feeding Ecology of the Primates of Bangladesh. In: Current Primatology Volume 1. University Louis Pasteur, Strasbourg. $86 \mathrm{pp}$.

Alom, A.S. 2015. Ecology and behavior of Capped Langur in Satchari National Park. M.Sc thesis (unpubl.), Department of Zoology, Jahangirnagar University, Savar, Dhaka. 15-62. 
Altman, J. 1974. Observational study of behavioral sampling methods. Behaviour 49: 222-267.

Badal, B.H. 2011. Ecology and behavior of Rhesus Macaque in Shariatpur, Bangladesh. M.Sc thesis (unpubl), Department of Zoology, Jahangirnagar University, Savar, Dhaka. 13-40.

Beckwith, R.S. 1995. The ecology and behaviour of the Javan Black Langur, in lower montane rain forest, West Java. PhD thesis (unpubl), University of Cambridge, Cambridge. 288 pp.

Chivers, D.J. and Hladik, C.M. 1984. In:Chivers, D.J., Wood, B.A. and Bilsborough, A. Food Acquisition and Processing in Primates. Plenum press, New York. 83-301 pp.

Clutton-Brock, T.H. 1974. Activity patterns of Red Colobus (Colobus badiustephrosceles). Folia Primatol. 21: 161-187.

Clutton-Brock, T.H. 1977. Some Aspects of Intraspecific Variation in Feeding and Ranging Behaviour in Primates. London: Academic Press. 539-556 pp.

Clutton-Brock, T.H. and Harvey, P.H. 1977. Species Differences in Feeding and Ranging Behaviour in Primates. London: Academic Press. 557-583 pp.

Dunbar, R.I.M. 1992. A model of the gelada socio-ecological system. Primates 33: 69-83.

Feeroz, M.M., Islam, M.A. and Kabir, M.M. 1995. Status and distribution and conservation of primates of Bangladesh. Kyoto University. Overseas Research Project of Study on Asian Non-human primates 9:73-82.

Freeland, W.J. and Janzen, D.H. 1974. Strategies in herbivory by mammals: The role of plant secondary compounds. The American Naturalist 108(961): 269-289.

Gittins, S.P. 1979. The behaviour and ecology of the Agile Gibbon. PhD dissertation, University of Cambridge, England.

Hosen, M.S. 2011. Ecology and behavior of Rhesus Macaque at Madhupur National Park. M.Sc thesis (unpubl.), Department of Zoology, Jahangirnagar University, Savar, Dhaka. 12-46.

IUCN 2016. The IUCN red list of threatened species. Accessed on 20 December 2015.

IUCN-Bangladesh 2015. Red List of Bangladesh, Volume 2: Mammals. IUCN-Bangladesh, Dhaka, Bangladesh. 232 pp.

Jaman, M.F. and Huffman, M.A. 2008. Enclosure environment affects the activity budgets of captive Japanese Macaques (Macaca fuscata). American J. Primatol. 70: 1133-1144.

Jaman, M.F., Huffman, M.A. and Takemoto, H. 2010. The foraging behavior of Japanese Macaques (Macaca fuscata) in a forested enclosure: Effects of nutrient composition, energy and its seasonal variation on the consumption of natural plant foods. Current Zoology 56(2): 198-208.

Jaman, M.F. and Huffman, M.A. 2013. The effect of urban and rural habitats and resource type on activity budgets of commensal Rhesus Macaques (Macaca mulatta) in Bangladesh. Primates 54: 49-59.

Kabir, M.M. 1991. Ecology and behaviour of Capped Langur in West Bhanugach Reserve Forest and Madhupur National Park. M.Sc thesis (unpubl.), Department of Zoology, Jahangirnagar University, Savar, Dhaka. 11-50.

Kabir, M.M. 2006. Activity pattern of Capped Langur in the Rema-Kalenga Wildlife Sanctuary of Bangladesh. Bangladesh J.Life Sci. 18(2): 59-69.

Khan, M.M.H. 2008. Protected Areas of Bangladesh- A Guide to Wildlife. Nishorgo Program, Bangladesh Forest Department, Dhaka. Bangladesh. 67 pp.

Khan, M.M.H. 2014. Introduction to the Wildlife of Bangladesh. Jahangirnagar University and Bangladesh Forest Department, Dhaka, Bangladesh. 27 pp.

Mandal, B.K. and Kabir, M.M. 2014. Ecology and behavior of Capped Langur (Trachypithecus pileatus, Blyth, 1843) in the moist deciduous forest of Bangladesh. Jagannath University J. Sci. 3(1): 65-77.

Molur, S., Brandon-Jones, W., Dittus, A.A., Eudey, A., Kumar, M., Singh, M., Feeroz, M.M., Chalise, P., Priya, P. and Walker, S. 2003. Status of South Asian Primates. CBSG, South Asia. IUCN/SSC Primate Specialist Group, Coimbatore, India. 
Oates, J.F. 1977. The Guereza and its Food. In: Glutton- Brock, T.H. (ed.). Primate ecology: Studies of feeding and ranging behavior in lemurs, monkeys and apes. London: Academic Press. 275-321 pp.

Roonwal, M.L. and Mohnot, S.M. 1977. Primates of South Asia: Ecology, Sociology and Behaviour. Havard University Press, Cambridge, UK. 5-67 pp.

Sarker, G.C., Kabir, M.M., Feeroz, M.M. and Hasan, M.K. 2008. Food and feeding behaviour of Rhesus Macaque (Macaca mulatta) at Barmi, Gazipur, Bangladesh. Bangladesh J. Life Sci. 20(2): 1-8.

Solanki, G.S., Kumar, A. and Sharma, B.K. 2008. Feeding ecology of Capped Langur in India. Int. J. Primatol. 29: 173-182. 